\title{
A sensitive non-radioactive in situ hybridization method for the detection of chicken IgG $\gamma$-chain mRNA: a technique suitable for detecting of variety of mRNAs in tissue sections
}

\author{
Weiming Zheng ${ }^{1}$, Junichi Izaki $^{2}$, Shuichi Furusawa ${ }^{2}$ and Yukinori Yoshimura ${ }^{2} *$ \\ ${ }^{1}$ Graduate School for International Development and Cooperation and ${ }^{2}$ Faculty of Applied Biological Science, Hiroshima \\ University, Higashi-Hiroshima, 739-8528, Japan
}

\begin{abstract}
*To whom correspondence should be addressed: Yoshimura Y., Faculty of Applied Biological Science, Hiroshima University, Higashi-Hiroshima, 739-8528, Japan. Tel/Fax: +81-824-24-7958. Email: yyosimu@ hiroshima-u.ac.jp
\end{abstract}

Submitted: March 5, 2001 Revised: May 2, 2001 Accepted: May 4, 2001 Published: May 14, 2001.

Indexing terms: in situ hybridization, IgG $\gamma$-chain mRNA, chicken

\begin{abstract}
We established a sensitive non-radioactive in situ hybridization (ISH) method for the detection of chicken IgG $\gamma$-chain mRNA in paraffin sections. RNA probes were transcribed in vitro from cloned chicken IgG $\mathrm{CH} 1$ nucleotide sequences with SP6/T7 RNA polymerases in the presence of DIG-UTP. These probes were used for hybridization and were immunodetected using anti-DIG antibodies conjugated to horseradish peroxidase. The immunoreactive products were visualized with $\mathrm{DAB}-\mathrm{H}_{2} \mathrm{O}_{2}$. IgG $\gamma$-chain mRNAexpressing cells were localized in both the spleen and oviductal tissues. This method demonstrated an excellent sensitivity since the ISH signal was clear and the background was negligible. We found that in the spleen $\mathrm{IgG}$ $\gamma$-chain mRNA-expressing cells were present mainly in the red pulp, whereas in the oviduct they appeared mainly in the mucosal stroma and not in the mucosal epithelium.
\end{abstract}

\section{INTRODUCTION}

In situ hybridization (ISH) is an effective approach for the localization of gene expression at the cytological level. It is an elegant synthesis of molecular biology and histology. The principle of ISH is the specific annealing of a labeled probe to complementary sequences of target nucleic acids in a fixed specimen, followed by detection and visualization of nucleic acid hybrids with cytological methods (1). In a study of local immunity in the chicken oviduct, we found that IgGpositive cells were present in both the mucosal epithelium and stroma (2). We then examined whether the IgG-positive cells in both the mucosal epithelium and the stroma produce IgG. To answer this question, we conducted ISH to investigate the gene expression using RNA probes that were specific to the $\operatorname{IgG} \gamma$-chain $\mathrm{CH} 1$ sequence. The results indicated that IgG $\gamma$-chain mRNA-expressing cells were present only in the mucosal stroma, and not in the mucosal epithelium (3). The protocol we used was highly effective and convenient. Although there are many descriptions of ISH methods and protocols (1), no protocol is universally sensitive and efficient, due to the huge scope of target nucleic acids and wide variance of tissue types. No ISH protocol for the detection of chicken IgG mRNA expression is established. Here we present our method in detail and discuss its features to allow others to use it effectively.

\section{MATERIALS AND METHODS}

\section{Preparation of tissue samples}

Tissue samples used in this experiment were collected from White Leghorn laying hens (57 weeks old). After decapitation, the spleen and small pieces (about $10 \mathrm{~mm}$ long) of the oviduct were quickly excised and washed briefly in PBS and fixed in newly-prepared 4\% (w/v) paraformaldehyde in PBS at $4{ }^{\circ} \mathrm{C}$ for $4 \mathrm{~h}$. Then the tissue samples were trimmed to small tissue blocks (3-5 $\mathrm{mm}$ long), put into plastic tissue cassettes and fixed again at $4{ }^{\circ} \mathrm{C}$ in the same fixative for another $20 \mathrm{~h}$. The tissues were dehydrated with a graded series of ethanol $(70 \%, 12$ h; 80\%, 6 h; 90\%, 6 h; absolute-I, $2 \mathrm{~h}$; absolute-II, $12 \mathrm{~h}$ ), cleared in xylene [creosote-xylene (1:4), $0.5 \mathrm{~h}$; xylene-I, $0.5 \mathrm{~h}$; xylene-II, $0.5 \mathrm{~h}$ ], infiltrated with paraffin ( 2 times, $2 \mathrm{~h}$ each), and embedded in paraffin wax. Sections, $6 \mu \mathrm{m}$ thick, were air-dried on 3-aminopropyl triethoxysilane-coated glass slides (4). All handling of tissues and sections was performed under RNase-free conditions.

\section{In Situ Hybridization}

Preparation of riboprobes Chicken IgG CH1 DNA fragments (5) were obtained as the PCR product. Briefly, total RNA was isolated from chicken (White Leghorn H-B 15) splenic cells using ISOGEN-LS (Takara, Tokyo, Japan). Poly (A)+ RNA was purified from total RNA using Oligotex-dT30 (Nippon Roche, Tokyo, Japan). The poly (A)+ RNA was

(C) 2001Biological Procedures Online. All rights reserved. Paper-based copying and internal distribution permitted for educational or non-profit purposes. Printing for personal use permitted. Electronic copying, storage or redistribution prohibited. 
reverse-transcribed using the SuperScript preamplification system (GIBCO-BRL, MD, USA), according to the manufacturer's instructions. The cDNA was extracted and PCR amplification was carried out using AmpliTaq-Gold DNA polymerase (Perkin Elmer, NJ, USA) and the following primers, AG1: GACGAAGCTT TTCCTCTTCT and GS1: CCCGATTGTA CCCTCTATCG (18-217 in CH1 domain). PCR was performed in a Program temp control system PC-700 thermal cycler (ASTEC Inc., Fukuoka, Japan). PCR products were ligated to the PGEM-T easy vector (Promega, WI, USA) according to the manufacturer's instructions. The cDNA insert was sequenced by an automated Applied Biosystems Model 373A sequencing system using a dye terminator sequencing kit (Amersham Pharmacia Biotech, NJ, USA). The resulting nucleotide sequence was exactly the same as reported by Parvari et al. (1988) (see Fig. 1). Antisense and sense riboprobes labeled with digoxigenin were prepared by using a DIG RNA labeling kit (SP6/T7) (Boehringer Mannheim Co. IN, USA) according to the manufacturer's instructions. Probes were stored in TE buffer (10 mM Tris-HCl, 1 mM EDTA, pH7.4) and used within two months.

\section{GACGAAGCTT TTCCTCTTCT CGCCGGGGCT 30 \\ GAGGCGGACG AAGCTGAGCT TCACGGGGGT 60 \\ CCCCGAAACT CTGCCGGCCA CCGCCGTACC 90 \\ TCCGGAGCCC TCCCAGGAGA TGCCGCCGGC 120 \\ GGACGAAGGG GACAACAGGC AGCCCACGGC 150 \\ CGGCGGGACA GCCGAGTCGG AACAACAGGC 180 \\ GGATAGAGGG TACAATCGGG \\ 200}

Fig. 1 Sequence of chicken IgG cDNA used in this study

In situ hybridization procedure. All steps prior to and during hybridization were conducted under RNase-free conditions. Sections were deparaffinized with xylene $(5 \mathrm{~min}$ $\mathrm{X} 3$ times), and rehydrated through descending ethanol concentrations [100\% (5 min X 3 times), 90\%, 80\%, 70\% and 50\% (5 min each) and PBS (10 min). The sections were treated with proteinase $\mathrm{K}, 2 \mu \mathrm{g} / \mathrm{ml}$ in PBS, $\mathrm{pH} 7.4$ at room temperature (RT, about $20^{\circ} \mathrm{C}$ ) for $15 \mathrm{~min}$. The slides were then immersed in $0.2 \%(\mathrm{w} / \mathrm{v})$ glycine in PBS $(10 \mathrm{~min})$ and PBS ( 3 min X 2 times). The sections were acetylated for 20 min with $0.25 \%(\mathrm{v} / \mathrm{v})$ acetic anhydride in $0.1 \mathrm{M}$ triethanolamine (TEA), $\mathrm{pH} 8.0$ and the slides were washed twice in 4 X SSC (10 min each). The 1 X SSC solution consisted of $0.15 \mathrm{M}$ sodium chloride and $0.015 \mathrm{M}$ trisodium citrate. Following incubation with $50 \% \quad(\mathrm{v} / \mathrm{v})$ deioned formamide $/ 2 \mathrm{X} \mathrm{SSC}$ solution at $42^{\circ} \mathrm{C}$ for $30 \mathrm{~min}$, the sections were incubated with hybridization solution which contained approximately $0.5 \mu \mathrm{g} / \mathrm{ml}$ DIG-labelled probes in hybridization buffer $(50 \%$ deioned formamide, $10 \%(\mathrm{w} / \mathrm{v})$ dextran sulfate, 1 X Denhardt's solution and $200 \mu \mathrm{g} / \mathrm{ml}$ tRNA in $0.6 \mathrm{M} \mathrm{NaCl} ; 10 \mathrm{mM}$ Tris-HCl, pH7.4; $1 \mathrm{mM}$ EDTA, pH8.0). On each slide $100 \mu$ l hybridization solution were applied. Slides were then incubated in a humidified chamber at $42^{\circ} \mathrm{C}$ for $16 \mathrm{~h}$.

After hybridization, slides were sequentially washed with $50 \%$ (v/v) formamide/2 X SSC at $42^{\circ} \mathrm{C}(20 \mathrm{~min} \mathbf{X} 3$ times $)$ and NTE buffer $(0.5 \mathrm{M} \mathrm{NaCl}, 10 \mathrm{mM}$ Tris-HCl, $1 \mathrm{mM}$ EDTA, pH 8.0) at $37^{\circ} \mathrm{C}(5 \mathrm{~min})$. Then sections were treated with RNase A, $20 \mu \mathrm{g} / \mathrm{ml}$, in NTE buffer at $37^{\circ} \mathrm{C}$ for $30 \mathrm{~min}$, followed by washing with NTE buffer at $37^{\circ} \mathrm{C}$ for $5 \mathrm{~min}$, and with $0.1 \mathbf{X ~ S S C}$ at $42^{\circ} \mathrm{C}(20 \mathrm{~min} \mathbf{X} 3$ times $)$.

After washing with buffer $1(0.1 \mathrm{M}$ Tris, $0.15 \mathrm{M} \mathrm{NaCl}, \mathrm{pH}$ 7.5) at RT for $1 \mathrm{~min}$, the slides were incubated with $5 \%(\mathrm{w} / \mathrm{v})$ blocking reagent (Boehringer Mannheim GmbH, Germany) in buffer 1 at RT for $30 \mathrm{~min}$. Then the slides were incubated in a humidified chamber overnight at $4^{\circ} \mathrm{C}$ with sheep antiDIG antibody conjugated with horseradish peroxidase (Boehringer Mannheim GmbH, Germany), diluted to 1:100 in buffer 1 containing $1 \%$ blocking reagent. Slides were then washed with buffer 1 (15 $\mathrm{min} \mathbf{X} 2$ times) and PBS (5 min) at RT. Finally, the immunoreactions were visualized by incubating the sections with a DAB- $\mathrm{H}_{2} \mathrm{O}_{2}$ solution $[0.02 \%$ (w/v) 3, 3'-diaminobenzidine tetrahydrochloride (DAB) and $0.005 \%$ (v/v) $\mathrm{H}_{2} \mathrm{O}_{2}$ in $0.05 \mathrm{M}$ Tris-HCl buffer, $\mathrm{pH}$ 7.6] for 30$60 \mathrm{~min}$. Slides were counterstained with haematoxylin, dehydrated with alcohol, cleared with xylene and covered with a coverslip before observation.

Negative controls were conducted by the substitution of sense for anti-sense probes or by the omission of anti-sense probes in the hybridization solution. The sections were observed under a light microscope with a Victor TK-1270 RGB color video camera (Victor, Tokyo) and a computer system ImagePro Plus 3.01 (Media Cybernetics ${ }^{\mathrm{TM}}$, Maryland, USA).

\section{RESULTS AND DISCUSSION}

Expression of $\operatorname{IgG} \gamma$-chain mRNA was clearly detected in all the sections hybridized with the anti-sense probes (Fig. 2a, c, and d), but not in the sections hybridized with sense probes (Fig. 2b), nor in the sections incubated with no probes (data not shown). These IgG mRNA-expressing cells are round or oval in shape (Fig. 2c). Almost no background (non-specific) staining was observed in any of the sections, suggesting that the current procedure is useful to detect specifically chicken IgG $\gamma$-chain mRNA. 


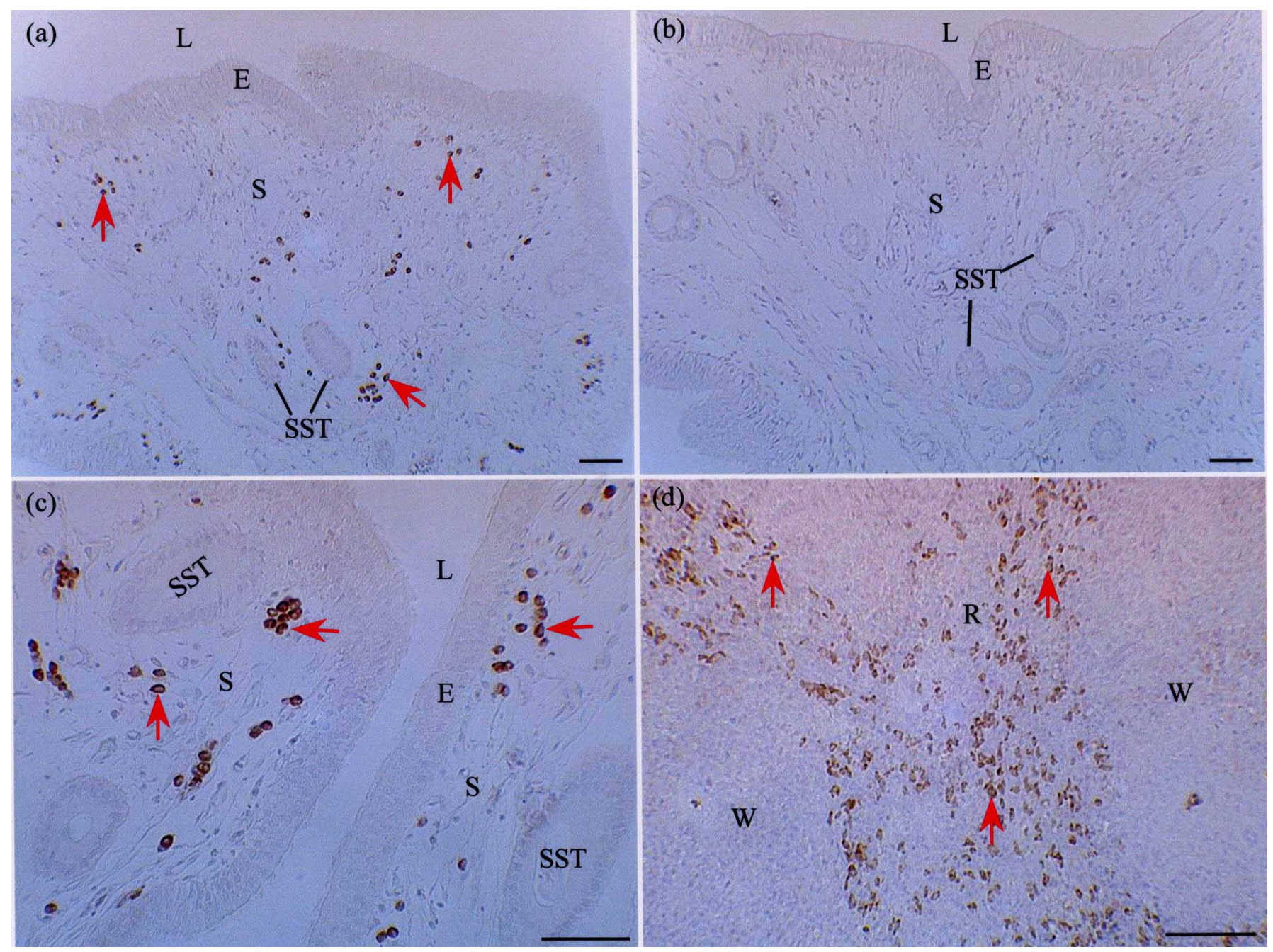

Fig. 2. Sections of chicken oviduct and spleen hybridized with $\operatorname{IgG} \gamma$-chain probes. Arrows indicate examples of $\operatorname{IgG} \gamma$-chain mRNA-expressing cells. E: mucosal epithelium; L: lumen of oviduct; S: mucosal stroma; SST: sperm storage tubules; R: red pulp; W: white pulp. Scale bars represent $50 \mu \mathrm{m}$. (a) Low magnification view of the oviductal uterovaginal junction (UVJ) after hybridization with IgG $\gamma$-chain anti-sense probes. (b) Low magnification view of UVJ after hybridization with IgG $\gamma$ chain sense probes. (c) Higher magnification view of UVJ after hybridization with IgG $\gamma$-chain anti-sense probes. (d) Higher magnification view of the spleen after hybridization with $\operatorname{IgG} \gamma$-chain anti-sense probes.

Generally, the ISH protocol used in this study consisted of five steps, which were (a) the preparation of probes, (b) preparation of tissue sections, (c) pretreatment of tissue sections to increase the accessibility of probes to $\gamma$-chain mRNA, (d) hybridization of probes to the tissue and posthybridization washes, and (e) detection and visualization of the nucleic acid hybrids. We used RNA probes to $\operatorname{IgG} \gamma$ chain mRNA. Although three types of probes, DNA, RNA and oligonucleotide probes, are generally used in ISH, RNA probes are the best and most sensitive for detecting mRNA transcripts because of the high thermal stability of the RNARNA hybrids $(1,6)$. Furthermore, in this study we used digoxigenin for the labeling of RNA probes, since digoxigenin is a hapten from plant and not animal cells, unlike biotin which is present in animal cells and which interferes with the detection of biotin-labeled probes (7). At present, high quality antibodies (sheep anti-DIG Fab fragment conjugated with horseradish peroxidase or alkaline phosphatase) are commercially available (Boehringer Mannheim GmbH, Mannheim, Germany). All these features of our methods would have contributed to the highly sensitive detection of specific $\operatorname{IgG} \gamma$-chain mRNAexpressing cells.

In this study we used freshly prepared 4\% PFA to fix the spleen and oviduct tissues immediately after dissection. The nature of the fixative, its concentration and the fixation time affect ISH results $(1,6)$. It has been reported that crosslinking fixatives (aldehydes) lead to greater retention of RNA in tissues than do precipitating fixatives (alcohol and acetone) (1). Fixative concentration and fixation time must be optimized to achieve a better retention of RNA, ideal

Biological Procedures Online • Vol. 3 No. $1 \bullet$ May 14, $2001 \bullet$ www.biologicalprocedures.com 
accessibility of the target nucleic acids and proper conservation of tissue morphology. Generally paraffin sections provide better cytological resolution than frozen sections. The glass slides must be properly coated with silane (4) and the tissue sections must be fully dried (at $40^{\circ} \mathrm{C}$ overnight) on the slides to provide optimal adhesion of tissue sections and prevent tissue loss during the entire process, especially during the long and stringent washes.

The purpose of the prehybridization treatment is to increase the accessibility of the target nucleic acids while reducing the ISH background. The main prehybridization treatment steps used in this study were deproteination and acetylation. We tried proteinase $\mathrm{K}(\mathrm{PK})$ for deproteination at different concentrations ( $1 \mu \mathrm{g}, 2 \mu \mathrm{g}, 10 \mu \mathrm{g} / \mathrm{ml})$, different temperatures (RT or $37^{\circ} \mathrm{C}$ ), and for different times $(5,10,15$ and $20 \mathrm{~min}$ ). We found that treatment of the tissues with PK at $2 \mu \mathrm{g} / \mathrm{ml}$, RT for 15 min produced ideal results based on both the signal density and the tissue morphology. We also observed that underdigestion reduced ISH signals and overdigestion caused the loss of morphological details (or even loss of tissue sections from the glass slide during ISH), as reported by other researchers $(8,9)$. It was reported that acetylation of tissue sections strongly increased specific ISH signals compared to non-acetylated sections (6). Baumgart et al. also showed that acetylation of tissue sections could reduce the background hybridization (1). Our results presented here support their observations. Furthermore, we have found that acetylation could also effectively improve the ISH signals when using PCR generated (DNA) probes (unpublished data).

Hybridization must be carried out under conditions which are favorable for the annealing of the probe to its target nucleic acid, and unfavorable for non-specific annealing. Several factors affect the stability of the hybrids formed. As mentioned before, RNA-RNA hybrids formed between RNA probes and target RNA are the most stable type of nucleic acid hybrids. In addition, the RNA probes used in this study were 200 bases long and their GC content was 68\% (Fig. 1). These characteristics of the probes would contribute to the increase in the accessibility of probes and the stability of the hybrids. We used moderate hybridization temperature $\left(42^{\circ} \mathrm{C}\right)$, low to medium probe concentration $(0.5 \mu \mathrm{g} / \mathrm{ml})$ and a long incubation time $(16 \mathrm{~h})$ for the ISH. Since RNA probes easily adhere to more than just their complementary RNA (10), the subsequent high stringency washes and RNase treatment would have deleted or decreased these nonspecific associations. Any single-stranded RNA was degraded by RNase, but the double-stranded RNA-RNA hybrids were RNase resistant (1), thus the hybridization conditions, posthybridization washes and RNase treatment contributed to the increase of signal and decrease of background staining in this study.
For the detection of ISH signals, POD-labeled Fab fragments and anti-DIG antibodies were used, which could penetrate into the tissue sections much better than the large complexes of complete antibodies coupled to POD. Furthermore, owing to the coupling of several Fab fragments to the same hapten (digoxigenin), a signal amplification was also achieved (1).

In conclusion, the ISH method reported here allows sensitive and efficient detection of chicken IgG heavy chain $\gamma$ gene expression in paraffin sections. Special attention was paid to the selection of probes, preparation and pretreatment of tissue sections, hybridization conditions, and posthybridization washes in order to achieve ideal ISH results.

\section{ACKNOWLEDGMENTS}

This work was supported by a Grant-in-Aid for Scientific Research (C), Ministry of Education, Sports and Science, Japan (No. 12660257).

\section{REFERENCES}

1. Baumgart E, Schad A, Grabenbauer M. In situ hybridization: general principles and application of digoxigenin-labeled cRNA for the detection of mRNAs. In Immunocytochemistry and In Situ Hybridization in the Biomedical Sciences. Ed Beesley JE. Boston, Birkhauser; 2001. p. 108-137.

2. Zheng WM, Yoshimura Y, Tamura T. Effects of sexual maturation and gonadal steroids on the localization of IgG-, IgM- and IgA-positive cells in the chicken oviduct. J. Reprod. Fertil. 1997; 111: 277-284.

3. Zheng WM, Izaki J, Furusawa S, Yoshimura Y. Localization of immunoglobulin $G \gamma$-chain mRNAexpressing cells in the oviduct of laying and diethylstilbestrol-treated immature hens. Gen. Comp. Endocri. 2000; 120: 345-352.

4. Van Prooijen-Knegt AC, Raaf AK, Van Der Burge MJ, Vrolijk J, Van Der Ploeg M. Spreading and staining of human metaphase chromosomes on aminoalkyl-salinetreated glass slides. Histochem. J. 1982; 14: 333-344.

5. Parvari R, Avivi A, Lentner F, Ziv E, Tel-Or S, Burstein Y, Schechter I. Chicken immunoglobulin gamma-heavy chains: limited VH gene repertoire, combinatorial diversification by $\mathrm{D}$ gene segments and evolution of the heavy chain locus. EMBO J 1988; 7: 739-744.

6. Braissant $\mathrm{O}$, Wahli W. A simplified in situ hybridization protocol using non-radioactively labeled probes to detect abundant and rare mRNAs on tissue sections. Biochemica 1998; 1: 10-16.

7. Chevalier J, Yi J, Michel O, Tang XM. Biotin and digoxigenin as labels for light and electron microscopy in situ hybridization probes: Where do we stand? $J$. Histochem. Cytochem. 1997; 45: 481-491. 
8. Baumgart E. Application of in situ hybridization, cytochemical and immunocytochemical techniques for the investigation of peroxisomes. A review including novel data. Histochem. Cell Biol. 1997; 108: 185-210.

9. Schad A, Fahimi HD, Volkl A, Baumgart E. Nonradioactive in situ hybridization for detection of mRNAs encoding for peroxisomal proteins: Heterogeneous hepatic lobular distribution after treatment with a single dose of bezafibrate. $J$. Histochem. Cytochem. 1996; 44:825-834.

10. Altar CA, Ryan S, Abood M, Eberwine JH. In situ hybridization: Standard procedures and novel approaches. In Methods in Neurosciences, Vol.1. Ed Conn PM. San Diego, Academic Press; 1989. p. 238291. 


\section{Reagents}

\section{PROTOCOL}

All solutions should be prepared with diethyl-pyrocarbonate (DEPC)-treated double distilled $\mathrm{H}_{2} \mathrm{O}\left(\mathrm{ddH}_{2} \mathrm{O}\right)$. Add $0.1 \%$ (v/v) DEPC into $\mathrm{ddH}_{2} \mathrm{O}$ and let it stand for 3-4 h with shaking. Then inactivate the DEPC by autoclaving.

1. 20\% paraformaldehyde (PFA): Dissolve 20g PFA in about $50 \mathrm{ml}$ PBS at $50-60^{\circ} \mathrm{C}$ with stirring. Add several drops of $5 \mathrm{~N} \mathrm{NaOH}$ to dissolve PFA thoroughly, then add equal volume of $5 \mathrm{~N} \mathrm{HCl}$. Finally add PBS to make the volume to $100 \mathrm{ml}$. After filtration, store at $4^{\circ} \mathrm{C}$ for use within 30 days. Dilute the stock to $4 \%$ working solution with PBS before use.

2. PBS buffer: $0.1 \mathrm{M} \mathrm{NaCl}, 0.01 \mathrm{M} \mathrm{NaH}_{2} \mathrm{PO}_{4}, \mathrm{pH}$ 7.4.

3. TE buffer: $10 \mathrm{mM}$ Tris, $1 \mathrm{mM}$ EDTA, $\mathrm{pH} 8.0$.

4. $100 \times$ Denhart's solution:

Ficoll (type 400, Pharmacia): $2 \mathrm{~g}$

Polyvinylpyrolidone: $\quad 2 \mathrm{~g}$

Bovine serum albumin: $\quad 2 \mathrm{~g}$

$\mathrm{ddH}_{2} \mathrm{O}$ to $100 \mathrm{ml}$

Filtrate through a $0.22 \mu \mathrm{m}$ sterile filter. Store at $4^{\circ} \mathrm{C}$.

5. Hybridization buffer

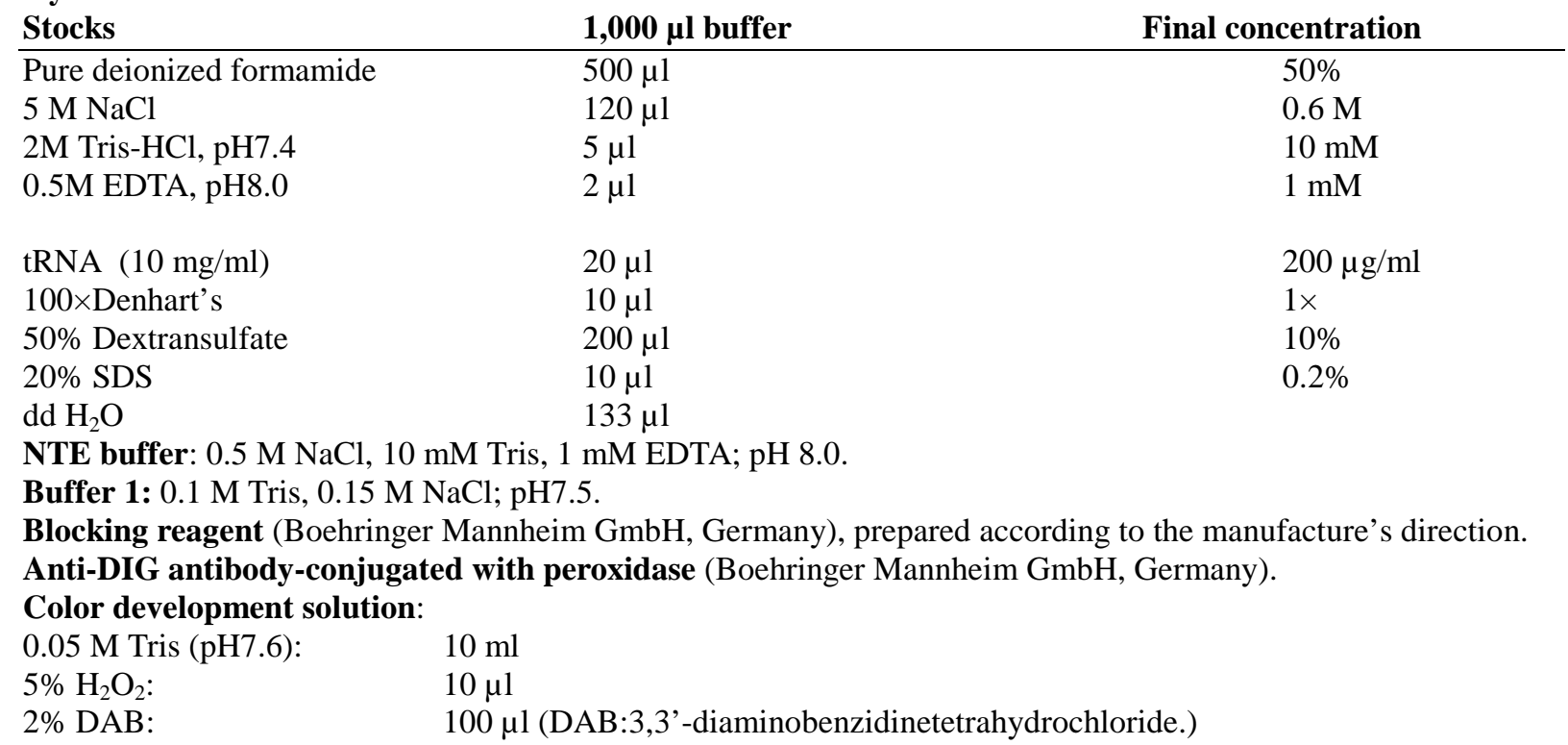

\section{In situ hybridization protocol}

Unless stated otherwise, all the operations were conducted at $20^{\circ} \mathrm{C}$.

1. Make paraffin sections on silane-coated glass slide. Dry the sections at $40^{\circ} \mathrm{C}$ overnight.

Prehybridization treatment

2. Deparaffinize and rehydrate: Pure xylene: $5 \mathrm{~min} \times 3$ times; $100 \%$ ethanol: $5 \mathrm{~min} \times 3$ times; $90 \%, 80 \%, 70 \%$ and 50\% ethanol: 5 min each. PBS: 10 min.

3. Proteinase $\mathrm{K}$ treatment: $2 \mu \mathrm{g} / \mathrm{ml}$ in PBS for $15 \mathrm{~min}$.

4. Incubate in PBS containing glycine $(2 \mathrm{mg} / \mathrm{ml})$ for $10 \mathrm{~min}$.

5. Wash in PBS, 3 min $\times 2$ times.

6. Acethylise by hanging the slide holder into a $500 \mathrm{ml}$ beaker, into which add $400 \mathrm{ml} 0.1 \mathrm{M}$ triethanolamine. Mix the solution with stirring. Add $1 \mathrm{ml}$ acetic anhydrate drop by drop in $5 \mathrm{~min}$. Then continue stirring for another 15 min.

7. Wash with $4 \times \mathrm{SSC}, 10 \mathrm{~min} \times 2$ times.

Hybridization

8. Incubate the sections with $50 \%$ deionized formamide/ $2 \times \mathrm{SSC}, 150 \mu \mathrm{l} / \mathrm{section}$, at $42^{\circ} \mathrm{C}$ for 30 min to inhibit nonspecific absorption of probes.

Biological Procedures Online • Vol. 3 No. $1 \bullet$ May 14, $2001 \bullet$ www.biologicalprocedures.com 
9. Prepare hybridization buffer and incubate it at $85^{\circ} \mathrm{C}$ water bath for $10 \mathrm{~min}$, then cool on ice. Add probes $(0.5$ $\mu \mathrm{g} / \mathrm{ml}$ ) into the buffer, mix well, incubate the mixture at $85^{\circ} \mathrm{C}$ in a water bath for $3 \mathrm{~min}$ to denature the probes, then cool on ice.

10. Add $100 \mu 1$ probe solution from above step on each section to cover the tissue properly. Place the sections in a box wetted with $50 \%$ formamide/ $2 \times$ SSC solution. Cover the box thoroughly to prevent drying.

11. Incubate at $42^{\circ} \mathrm{C}$ for $16 \mathrm{~h}$.

Post-hybridization washing

12. Wash the sections in $50 \%$ formamide $/ 2 \mathrm{XSSC}$ at $42^{\circ} \mathrm{C}, 20 \mathrm{~min} \times 3$ times.

13. Wash in NTE buffer at $37^{\circ} \mathrm{C}$ for $5 \mathrm{~min}$.

14. Treat the sections with RNase A in NTE buffer, $20 \mu \mathrm{g} / \mathrm{ml}$, at $37^{\circ} \mathrm{C}$ for $30 \mathrm{~min}$.

15. Wash in NTE buffer at $37^{\circ} \mathrm{C}$ for $5 \mathrm{~min}$.

16. Wash in $0.1 \times \mathrm{SSC}$ at $42^{\circ} \mathrm{C}, 20 \mathrm{~min} \times 3$ times.

Detection of signals

17. Equilibrate the sections in buffer 1 for $1 \mathrm{~min}$.

18. Block the sections in buffer 2 (buffer 1 with $5 \%$ blocking reagent) for $30 \mathrm{~min}$.

19. Incubate the sections at $4^{\circ} \mathrm{C}$ overnight with sheep anti-DIG-antibody conjugated with peroxidase, diluted 1:100 with buffer 1 containing $1 \%$ blocking reagent.

20. Wash the sections in buffer $1,15 \mathrm{~min} \times 2$ times.

21. Equilibrate the sections in PBS for 5 min.

22. Incubate the sections with DAB color development solution. Check the color development under a microscope. When the brown signal is dense and the background is low, stop the reaction by immersing the sections into running water.

23. Stain the background with haematoxylin briefly, dehydrate with ascending ethanol, clear with xylene and mount as usual. 